ISSN: 2362-1303 (Paper) | eISSN: 2362-1311(Online)

JOURNAL OF ADVANCED ACADEMIC RESEARCH (JAAR)

January 2015

\title{
Socio-cultural Causes of Gender Disparity in Nepalese Society
}

\section{Anita Shrestha ${ }^{1} \&$ Prof. Dr. Ritu Prasad Gartoulla ${ }^{2}$}

${ }^{1}$ PhD Scholar, Mewar University, Rajasthan, India

${ }^{2}$ Professor, Institute of Medicine, TU, Kathmandu, Nepal

Corresponding Author

Anita Shrestha

Email: anitashrestha26@gmail.com

\begin{abstract}
Gender is socially constructed idea and disparity is the problem created by the society. The study was conducted from the socio-cultural perspective so the main objective of this study was to identify the socio-cultural causes of gender disparity in five different ethnic groups: Newar, Magar, Tamang, Rai/Limbu and Brahmin/Chhetri of Kathmandu Valley. Total 390 respondents were selected randomly from the all ethnic groups. Except the role of religion, the role of culture, patriarchy system, social perception, sources of income, level of education, political awareness \& involvement and gender based division of labor had significant effect to increase the gender disparity in society. Political announcement that Nepal as a secular country had effected in the perception and practices related to the religious activities of people also. The government should address the socio-cultural problem and further researcher should explore the strategies to address the problem of gender disparity.
\end{abstract}

Keywords: Causes, Disparity, Gender, Nepal, Society, Socio-culture

\section{Introduction}

Society is the web of social relationship in one hand and on the other hand culture is man-made. People developed the culture to maintain the social norms, values and historical civilization in society. The cultural transformation and orientation determines the personality of every individual. There is interrelationship and interdependency between the culture and personality. When people feel suffocation because of the rigid cultural pattern, they try to break the traditional culture and reform the new culture to live the life in comfort zone.

Men and women always comprise the two halves of the population in every society. However, the rights and opportunities accorded to women have never been on per with the rights and opportunities accorded to men of the said societies. These differences in the opportunities of life found between men and women have forced women in many contexts to bear a subordinate position. This can be seen in a number of sectors, namely the economic, political, social, and cultural life of each society (Baker, 1999, p. 16). 
ISSN: 2362-1303 (Paper) | eISSN: 2362-1311(Online)

JOURNAL OF ADVANCED ACADEMIC RESEARCH (JAAR)

January 2015

In many countries, the birth of a boy becomes a reason to celebrate, whereas the birth of a girl is a disaster. Selective abortions of female fetuses and female infanticide are no exception, resulting in unnatural gender ratios.

A British Sociologist, Ann Oakley and a supporter of the Women's Liberation Movement, comes down strongly on the side of culture as the determinant of gender roles rather than biology. The sexual division of labour is supported and justified by a belief and value system which states that gender roles are normal, natural, right and proper (Heald M. H., 2010, p. 373). Study of the history of human society reveals that in no society of the world has women enjoyed absolute equality on par with men. Everywhere they were subjected to inequality, discrimination and exploitation (Rao, 2008, p. 813).Connell (1987) elaborated one of the most integrative theories of gender. This theory is important because it allows for an understanding of the complex interplay between gender and power beyond the individual perspective. A central emphasis of this theory is that the analysis of gender involves a three-part structural model involving sexual division of labor (e.g. financial inequality), sexual division of power (e.g. authority), and the structure of affective attachments (e.g. social norms) (Ngozi C Mbonu, 2010, p. 2).

In the Nepalese context, this gender based discrimination is mainly faith based, embedded with fear and myth, and is deep routed in the culture and social norms (SAMUHIK ABHIYAN, Mar 2008 , p. 25).Gender disparity is also one effect of cultural transformation. People practice the discriminatory behavior unknowingly also. They think it as the continuation of their culture. So, here researcher has tried to identify the role of socio-cultural practices to determine the degree of gender disparity in study areas.

\section{Method}

The study was based on the descriptive cross-sectional research design. Total 390 respondents were selected from the 5 different ethnic groups; Newar, Magar, Tamang, Rai/Limbu and Brahmin/Chhetri for the study, among them respondents were equally distributed in three districts; Kathmandu, Lalitpur and Bhaktpur. So, 130 respondents were selected from the each district. Following the objectives of this study, researcher had collected data by using the 5 points Likert scales. Simple random sampling technique was applied to select the respondents. Statistical analysis; cross tab, Chi-square and correlation test was done to show the significant association between the different ethnic groups.

\section{Result}

The demographic information of the study showed that there was $50.3 \%$ male followed by $49.7 \%$ female were participated in study. Data shows that $4.6 \%$ wife were illiterate followed by $1.8 \%$ husband. Similarly, in total, 7.7 husbands had master and above degree followed by only $2.1 \%$ wife. In the study, the age distribution of wife shows 20 to 60 years followed by 24-60 years of 
ISSN: 2362-1303 (Paper) | eISSN: 2362-1311(Online)

JOURNAL OF ADVANCED ACADEMIC RESEARCH (JAAR)

husbands. Mean age of wife was 35.46 years followed by 39.13 years of husband. Marriage age of wife was found in between the 15-31 followed by husband had in between 16-35 ages. The mean age of wife during her marriage was 21.53 years followed by husband had 24.84 years.

\section{Patriarchy system and gender disparity}

Majority of the Nepalese societies had patriarchy system. Male headed societies are there. So, researcher also collected the perceptual data on patriarchy system as a cause of gender disparity in community.

Table 1: Patriarchy system and gender disparity

\begin{tabular}{|c|c|c|c|c|c|c|c|}
\hline \multicolumn{8}{|c|}{ Patriarchy system causes the gender disparity in your community } \\
\hline & & \multicolumn{5}{|c|}{ Caste of Respondents } & \multirow[b]{2}{*}{ Total } \\
\hline & & Newar & Magar & Tamang & $\begin{array}{l}\text { Rai or } \\
\text { Limbu }\end{array}$ & $\begin{array}{c}\text { Brahmin or } \\
\text { Chhetri }\end{array}$ & \\
\hline \multirow{2}{*}{\begin{tabular}{|l} 
Strongly \\
Agree
\end{tabular}} & Count & 48 & 51 & 48 & 62 & 32 & 241 \\
\hline & $\%$ of Total & $12.4 \%$ & $13.2 \%$ & $12.4 \%$ & $16.0 \%$ & $8.3 \%$ & $62.3 \%$ \\
\hline \multirow{2}{*}{ Agree } & Count & 17 & 22 & 20 & 11 & 34 & 104 \\
\hline & $\%$ of Total & $4.4 \%$ & $5.7 \%$ & $5.2 \%$ & $2.8 \%$ & $8.8 \%$ & $26.9 \%$ \\
\hline \multirow{2}{*}{ Neutral } & Count & 5 & 1 & 1 & 3 & 1 & 11 \\
\hline & $\%$ of Total & $1.3 \%$ & $0.3 \%$ & $0.3 \%$ & $0.8 \%$ & $0.3 \%$ & $2.8 \%$ \\
\hline \multirow{2}{*}{ Disagree } & Count & 3 & 3 & 5 & 2 & 7 & 20 \\
\hline & $\%$ of Total & $0.8 \%$ & $0.8 \%$ & $1.3 \%$ & $0.5 \%$ & $1.8 \%$ & $5.2 \%$ \\
\hline \multirow{2}{*}{$\begin{array}{l}\text { Strongly } \\
\text { Disagree }\end{array}$} & Count & 3 & 1 & 3 & 0 & 4 & 11 \\
\hline & $\%$ of Total & $0.8 \%$ & $0.3 \%$ & $0.8 \%$ & $0.0 \%$ & $1.0 \%$ & $2.8 \%$ \\
\hline \multirow{2}{*}{ Total } & Count & 76 & 78 & 77 & 78 & 78 & 387 \\
\hline & $\%$ of Total & $19.6 \%$ & $20.2 \%$ & $19.9 \%$ & $20.2 \%$ & $20.2 \%$ & $100.0 \%$ \\
\hline
\end{tabular}

Sources: Field survey, 2014

$62.3 \%$ respondents strongly agreed that patriarchy system is one cause of gender disparity followed by $26.9 \%$ reported agree in the above statement. Caste wise, $16 \%$ Rai or Limbu followed by $13.2 \%$ Magar, $12.4 \%$ Newar and 12.4\% Tamang and 8.3\% Brahmin/Chhetri respondents strongly agreed on the perception that patriarchy system causes the gender disparity in all ethnic communities.

\section{Cultural taboos causes the gender disparity}

Socio-cultural orientation determined the personality development of individual. Cultural norms play the role of social law so people become compelled to accept the cultural barrier. Regarding 
ISSN: 2362-1303 (Paper) | eISSN: 2362-1311(Online)

JOURNAL OF ADVANCED ACADEMIC RESEARCH (JAAR)

this issue, the table no. 2 shows that $21.2 \%$ respondents were strongly agreed that cultural taboos causes the gender disparity followed by $30.1 \%$ agreed.

The data shows that regarding the cultural taboos as a cause of gender disparity, around $50 \%$ respondents were found in neutral and disagree.

Table 2: Cultural taboos causes the gender disparity

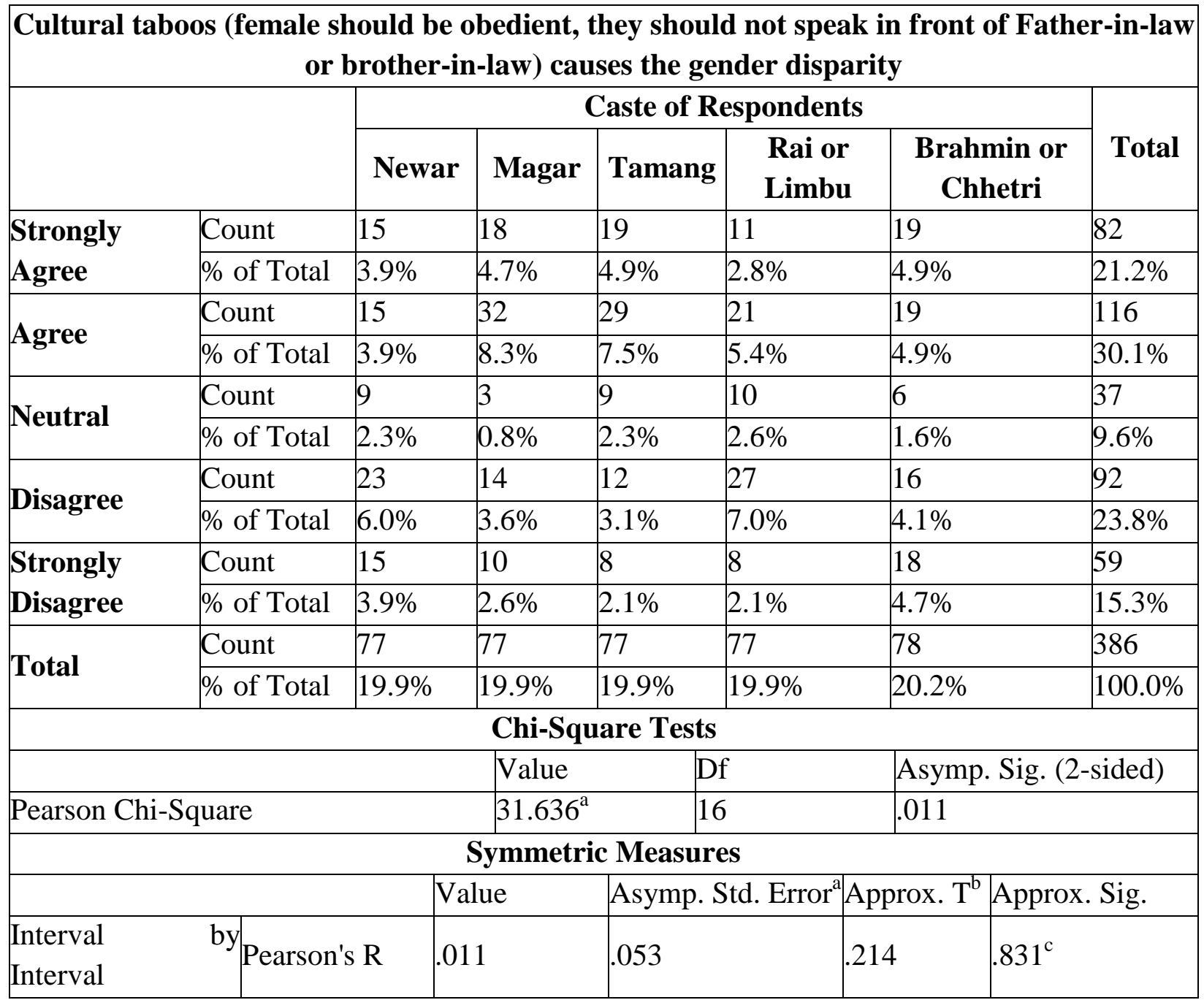

Sources: Field survey, 2014

There was significant association found on perception of five different ethnic groups $(\mathrm{p}=.011)$ regarding the cultural taboos as a causes of gender disparity. Similarly, there was significant relation $(\mathrm{r}=.011, \mathrm{p}=.053)$ found on perception of female and male regarding the cultural taboos as a causes of gender disparity. 
ISSN: 2362-1303 (Paper) | eISSN: 2362-1311(Online)

JOURNAL OF ADVANCED ACADEMIC RESEARCH (JAAR)

January 2015

3. Social perception toward gender that Male is stronger than female causes the gender disparity

Social perception is important to understand the meaning of phenomena. Social behavior is strongly guided by the social understanding. The table no. 3 shows that $63.6 \%$ respondents strongly agreed that gender disparity is caused by the social perception towards the gender that males are stronger than females followed by $21.8 \%$ agreed on the same statement.

Table 3: Social perception toward gender

\begin{tabular}{|l|l|l|l|l|l|l|}
\hline \multicolumn{2}{|c|}{ Social perception toward gender that Male is stronger than female causes the gender } \\
disparity
\end{tabular}

Sources: Field survey, 2014

There was significant association found on perception of five different ethnic groups $(\mathrm{p}=.016)$ regarding the perception of society that males are stronger than females as a causes of gender 
ISSN: 2362-1303 (Paper) | eISSN: 2362-1311(Online)

JOURNAL OF ADVANCED ACADEMIC RESEARCH (JAAR)

disparity. Similarly, there was significant relation $(r=.006, p=.055)$ found on perception of female and male regarding the perception of society that males are stronger than females as a causes of gender disparity.

\section{Religious belief that female should do the fasting for the welfare of family causes the gender disparity}

In total, $44.6 \%$ respondents were found disagree that religious belief that female should do the fasting for the welfare of family is one cause of gender disparity followed by $41.9 \%$ agree on the same statement. Comparatively, more people were found disagree on this cause than the no. of people who agree.

Table 4: Religious belief

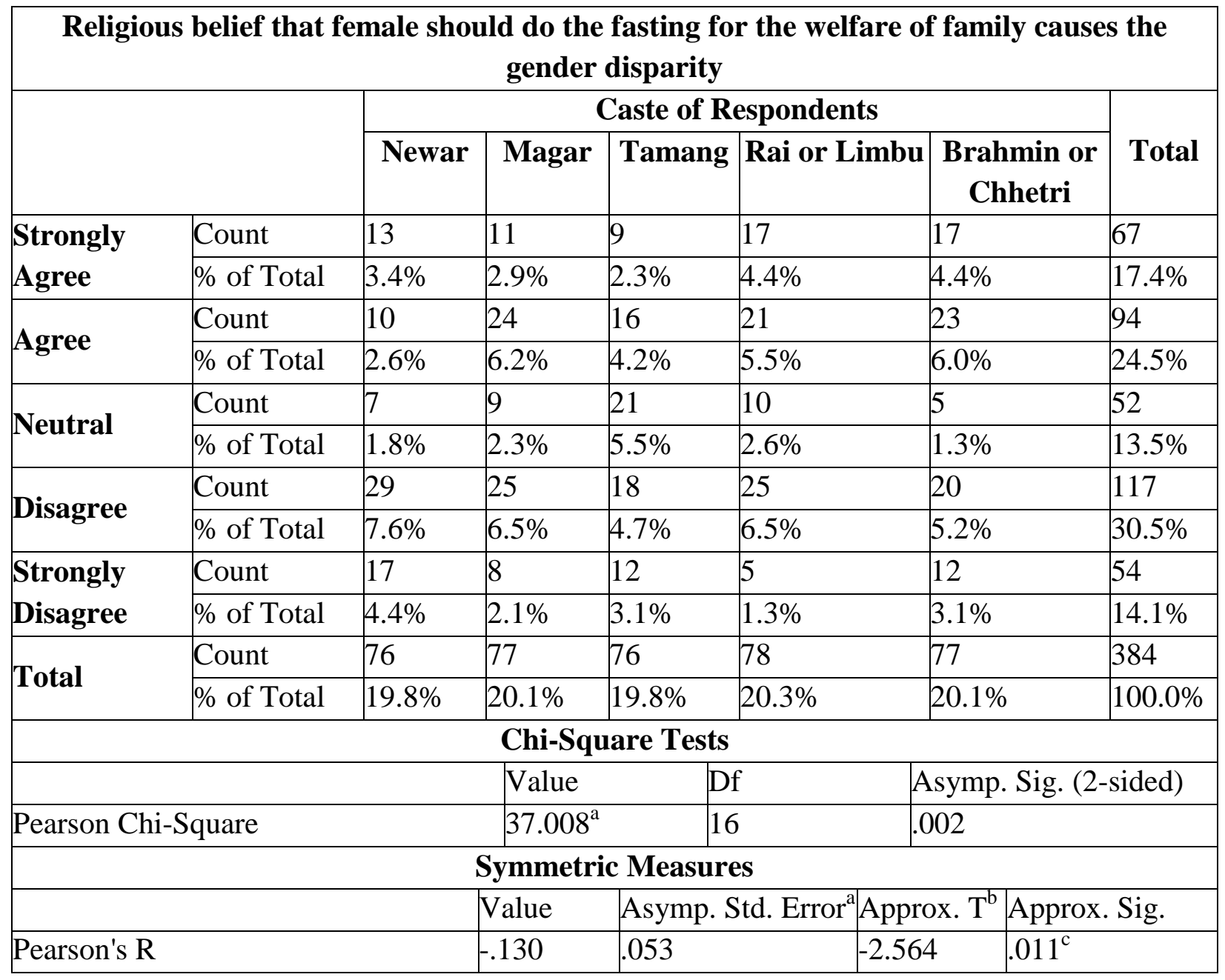

Sources: Field survey, 2014

There was significant association found on perception of five different ethnic groups $(\mathrm{p}=.016)$ regarding the religious belief on fasting of female as a causes of gender disparity. Similarly, 
ISSN: 2362-1303 (Paper) | eISSN: 2362-1311(Online)

JOURNAL OF ADVANCED ACADEMIC RESEARCH (JAAR)

there was significant relation $(\mathrm{r}=.006, \mathrm{p}=.055)$ found on perception of female and male regarding the religious belief on fasting of female as a causes of gender disparity

\section{Income causes the gender disparity}

Income of male and female also play the role to determine the gender relationship in family and society. Regarding this issue, $66.8 \%$ respondents strongly agree that income causes the gender disparity followed by $20.6 \%$ respondent found in agree in the same.

Table 5: Income causes the gender disparity

\begin{tabular}{|c|c|c|c|c|c|c|c|}
\hline \multicolumn{8}{|c|}{ Income causes the gender disparity } \\
\hline & & \multicolumn{5}{|c|}{ Caste of Respondents } & \multirow[b]{2}{*}{ Total } \\
\hline & & Newar & Magar & Tamang & $\begin{array}{l}\text { Rai or } \\
\text { Limbu }\end{array}$ & $\begin{array}{c}\text { Brahmin or } \\
\text { Chhetri }\end{array}$ & \\
\hline \multirow{2}{*}{$\begin{array}{l}\text { Strongly } \\
\text { Agree }\end{array}$} & Count & 50 & 53 & 50 & 64 & 39 & 256 \\
\hline & $\%$ of Total & $13.1 \%$ & $13.8 \%$ & $13.1 \%$ & $16.7 \%$ & $10.2 \%$ & $66.8 \%$ \\
\hline \multirow{2}{*}{ Agree } & Count & 14 & 22 & 18 & 8 & 17 & 79 \\
\hline & $\%$ of Total & $3.7 \%$ & $5.7 \%$ & $4.7 \%$ & $2.1 \%$ & $4.4 \%$ & $20.6 \%$ \\
\hline \multirow{2}{*}{ Neutral } & Count & 3 & 0 & 1 & 3 & 6 & 13 \\
\hline & $\%$ of Total & $0.8 \%$ & $0.0 \%$ & $0.3 \%$ & $0.8 \%$ & $1.6 \%$ & $3.4 \%$ \\
\hline \multirow{2}{*}{ Disagree } & Count & 6 & 3 & 5 & 2 & 7 & 23 \\
\hline & $\%$ of Total & $1.6 \%$ & $0.8 \%$ & $1.3 \%$ & $0.5 \%$ & $1.8 \%$ & $6.0 \%$ \\
\hline \multirow{2}{*}{$\begin{array}{l}\text { Strongly } \\
\text { Disagree }\end{array}$} & Count & 3 & 0 & 3 & 1 & 5 & 12 \\
\hline & $\%$ of Total & $0.8 \%$ & $0.0 \%$ & $0.8 \%$ & $0.3 \%$ & $1.3 \%$ & $3.1 \%$ \\
\hline \multirow{2}{*}{ Total } & Count & 76 & 78 & 77 & 78 & 74 & 383 \\
\hline & $\%$ of Total & $19.8 \%$ & $20.4 \%$ & $20.1 \%$ & $20.4 \%$ & $19.3 \%$ & $100.0 \%$ \\
\hline
\end{tabular}

Sources: Field survey, 2014

Ethnicity wise, out of $66.8 \%$ responses, $16.7 \%$ Rai/Limbu found strongly agrees that income is one cause of gender disparity compared with $10.2 \%$ Brahmin/Chhetri.

\section{Illiteracy causes the gender disparity}

Education is the light of knowledge. So, it supports to understand the social norms and values and also teach to solve the social problem and makes life easy for the social adjustment. Gender disparity is one social problem, created from the perception and practices of society. So, researcher asked respondent about the role of education in gender disparity. 
ISSN: 2362-1303 (Paper) | eISSN: 2362-1311(Online)

JOURNAL OF ADVANCED ACADEMIC RESEARCH (JAAR)

Table 6: Illiteracy causes the gender disparity

\begin{tabular}{|c|c|c|c|c|c|c|c|}
\hline \multicolumn{8}{|c|}{ Illiteracy causes the gender disparity } \\
\hline & & \multicolumn{5}{|c|}{ Caste of Respondents } & \multirow[b]{2}{*}{ Total } \\
\hline & & Newar & Magar & Tamang & $\begin{array}{l}\text { Rai or } \\
\text { Limbu }\end{array}$ & $\begin{array}{c}\text { Brahmin or } \\
\text { Chhetri }\end{array}$ & \\
\hline \multirow{2}{*}{$\begin{array}{l}\text { Strongly } \\
\text { Agree }\end{array}$} & Count & 54 & 56 & 53 & 62 & 47 & 272 \\
\hline & $\%$ of Total & $14.0 \%$ & $14.5 \%$ & $13.7 \%$ & $16.1 \%$ & $12.2 \%$ & $70.5 \%$ \\
\hline \multirow{2}{*}{ Agree } & Count & 14 & 19 & 20 & 13 & 18 & 84 \\
\hline & $\%$ of Total & $3.6 \%$ & $4.9 \%$ & $5.2 \%$ & $3.4 \%$ & $4.7 \%$ & $21.8 \%$ \\
\hline \multirow{2}{*}{ Neutral } & Count & 3 & 0 & 3 & 1 & 3 & 10 \\
\hline & $\%$ of Total & $0.8 \%$ & $0.0 \%$ & $0.8 \%$ & $0.3 \%$ & $0.8 \%$ & $2.6 \%$ \\
\hline \multirow{2}{*}{ Disagree } & Count & 4 & 2 & 0 & 2 & 6 & 14 \\
\hline & $\%$ of Total & $1.0 \%$ & $0.5 \%$ & $0.0 \%$ & $0.5 \%$ & $1.6 \%$ & $3.6 \%$ \\
\hline \multirow{2}{*}{$\begin{array}{l}\text { Strongly } \\
\text { Disagree }\end{array}$} & Count & 2 & 0 & 1 & 0 & 3 & 6 \\
\hline & $\%$ of Total & $0.5 \%$ & $0.0 \%$ & $0.3 \%$ & $0.0 \%$ & $0.8 \%$ & $1.6 \%$ \\
\hline \multirow{2}{*}{ Total } & Count & 77 & 77 & 77 & 78 & 77 & 386 \\
\hline & $\%$ of Total & $19.9 \%$ & $19.9 \%$ & $19.9 \%$ & $20.2 \%$ & $19.9 \%$ & $100.0 \%$ \\
\hline
\end{tabular}

Sources: Field survey, 2014

In total, $70.5 \%$ respondents strongly agree that illiteracy is one cause of gender disparity followed by $21.8 \%$ agree on the same cause. In total, more than $90 \%$ respondents agreed that illiteracy is one cause of gender disparity.

\section{Lack of political awareness causes the gender disparity}

Politics of country prepared the rules and regulation of social development and change. $27.2 \%$ respondents followed by $25.1 \%$ respectively strongly agree and agree on the statement that lack of political awareness causes the gender disparity. Around $30 \%$ respondents disagree on the same cause followed by $19.1 \%$ had neutral response.

Table 7: Lack of political awareness causes the gender disparity

\begin{tabular}{|c|c|c|c|c|c|c|c|}
\hline \multicolumn{8}{|c|}{ Lack of political awareness causes the gender disparity } \\
\hline & & \multicolumn{5}{|c|}{ Caste of Respondents } & \multirow[b]{2}{*}{ Total } \\
\hline & & Newar & Magar & Tamang & $\begin{array}{l}\text { Rai or } \\
\text { Limbu }\end{array}$ & $\begin{array}{c}\text { Brahmin or } \\
\text { Chhetri }\end{array}$ & \\
\hline \multirow{2}{*}{$\begin{array}{l}\text { Strongly } \\
\text { Agree } \\
\end{array}$} & Count & 27 & 13 & 28 & 23 & 13 & 104 \\
\hline & $\%$ of Total & $7.0 \%$ & $3.4 \%$ & $7.3 \%$ & $6.0 \%$ & $3.4 \%$ & $27.2 \%$ \\
\hline \multirow{2}{*}{ Agree } & Count & 18 & 23 & 17 & 27 & 11 & 96 \\
\hline & $\%$ of Total & $4.7 \%$ & $6.0 \%$ & $4.4 \%$ & $7.0 \%$ & $2.9 \%$ & $25.1 \%$ \\
\hline
\end{tabular}


ISSN: 2362-1303 (Paper) | eISSN: 2362-1311(Online)

JOURNAL OF ADVANCED ACADEMIC RESEARCH (JAAR)

\begin{tabular}{|c|c|c|c|c|c|c|c|}
\hline \multirow{2}{*}{ Neutral } & Count & 11 & 18 & 17 & 14 & 13 & 73 \\
\hline & $\%$ of Total & $2.9 \%$ & $4.7 \%$ & $4.4 \%$ & $3.7 \%$ & $3.4 \%$ & $19.1 \%$ \\
\hline \multirow{2}{*}{ Disagree } & Count & 16 & 13 & 8 & 10 & 17 & 64 \\
\hline & $\%$ of Total & $4.2 \%$ & $3.4 \%$ & $2.1 \%$ & $2.6 \%$ & $4.4 \%$ & $16.7 \%$ \\
\hline \multirow{2}{*}{\begin{tabular}{|l} 
Strongly \\
Disagree
\end{tabular}} & Count & 5 & 9 & 7 & 4 & 21 & 46 \\
\hline & $\%$ of Total & $1.3 \%$ & $2.3 \%$ & $1.8 \%$ & $1.0 \%$ & $5.5 \%$ & $12.0 \%$ \\
\hline \multirow{2}{*}{ Total } & Count & 77 & 76 & 77 & 78 & 75 & 383 \\
\hline & $\%$ of Total & $20.1 \%$ & $19.8 \%$ & $20.1 \%$ & $20.4 \%$ & $19.6 \%$ & $100.0 \%$ \\
\hline \multicolumn{8}{|c|}{ Chi-Square Tests } \\
\hline & & & \multicolumn{2}{|c|}{ Value } & & \multicolumn{2}{|c|}{ Asymp. Sig. (2-sided) } \\
\hline \multicolumn{3}{|c|}{ Pearson Chi-Square } & \multicolumn{2}{|c|}{$45.841^{\mathrm{a}}$} & & \multicolumn{2}{|l|}{.000} \\
\hline \multicolumn{8}{|c|}{ Symmetric Measures } \\
\hline & & & \multirow{2}{*}{\begin{tabular}{|l} 
Value \\
134
\end{tabular}} & \multicolumn{2}{|c|}{ Asymp. Std. Error ${ }^{a}$} & \multicolumn{2}{|c|}{\begin{tabular}{|l|l} 
Approx. $T^{b}$ & Approx. Sig. \\
\end{tabular}} \\
\hline \multicolumn{3}{|c|}{ Interval by Interval Pearson's R } & & 052 & & 2.644 & \\
\hline
\end{tabular}

Sources: Field survey, 2014

There was significant association found on perception of five different ethnic groups $(\mathrm{p}=.000)$ regarding the illiteracy as a causes of gender disparity. Similarly, there was significant relation $(\mathrm{r}$ $=.134, \mathrm{p}=.052$ ) found on perception of female and male regarding the illiteracy as a cause of gender disparity.

\section{Gender based division of labor causes the gender disparity}

We can observe in many work places that there is gender based division of labor. Basically, physically males are taken stronger than females. In government job also, very few female can be seen in the decision making level.

Table 8: Gender based division of labor causes the gender disparity

\begin{tabular}{|c|c|c|c|c|c|c|c|}
\hline \multicolumn{8}{|c|}{ Gender based division of labor causes the gender disparity } \\
\hline & & \multicolumn{5}{|c|}{ Caste of Respondents } & \multirow[b]{2}{*}{ Total } \\
\hline & & Newar & Magar & Tamang & $\begin{array}{l}\text { Rai or } \\
\text { Limbu }\end{array}$ & $\begin{array}{c}\text { Brahmin or } \\
\text { Chhetri }\end{array}$ & \\
\hline \multirow{2}{*}{$\begin{array}{l}\text { Strongly } \\
\text { Agree }\end{array}$} & Count & 55 & 55 & 52 & 65 & 42 & 269 \\
\hline & $\%$ of Total & $14.4 \%$ & $14.4 \%$ & $13.6 \%$ & $17.0 \%$ & $11.0 \%$ & $70.2 \%$ \\
\hline \multirow{2}{*}{ Agree } & Count & 13 & 16 & 14 & 8 & 22 & 73 \\
\hline & $\%$ of Total & $3.4 \%$ & $4.2 \%$ & $3.7 \%$ & $2.1 \%$ & $5.7 \%$ & $19.1 \%$ \\
\hline \multirow{2}{*}{ Neutral } & Count & 3 & 2 & 5 & 1 & 3 & 14 \\
\hline & $\%$ of Total & $0.8 \%$ & $0.5 \%$ & $1.3 \%$ & $0.3 \%$ & $0.8 \%$ & $3.7 \%$ \\
\hline Disagree & Count & 5 & 2 & 2 & 3 & 6 & 18 \\
\hline
\end{tabular}


ISSN: 2362-1303 (Paper) | eISSN: 2362-1311(Online)

JOURNAL OF ADVANCED ACADEMIC RESEARCH (JAAR)

\begin{tabular}{|l|l|l|l|l|l|l|l|}
\hline \multirow{3}{*}{$\begin{array}{l}\text { Strongly } \\
\text { Disagree }\end{array}$} & \%of Total & $1.3 \%$ & $0.5 \%$ & $0.5 \%$ & $0.8 \%$ & $1.6 \%$ & $4.7 \%$ \\
\hline \multirow{2}{*}{ Total } & Count & 1 & 1 & 3 & 1 & 3 & 9 \\
\hline & Count & 77 & 76 & 76 & 78 & 76 & 383 \\
\cline { 2 - 8 } & $\%$ of Total & $20.1 \%$ & $19.8 \%$ & $19.8 \%$ & $20.4 \%$ & $19.8 \%$ & $100.0 \%$ \\
\hline
\end{tabular}

Sources: Field survey, 2014

In response of participants, $70.2 \%$ respondents responded strongly agree followed by $19.1 \%$ responded agree that gender based division of labour is one cause of gender disparity. In total, around $90 \%$ respondents agreed that gender based division of labour causes the gender disparity.

\section{Discussion}

As the finding of the study showed that around 90\% respondents had agreed patriarchal culture had contributed to gender disparity in Nepalese society. From the previous study, it was reported that historically the development of Hindu society has been one of ever increasing hierarchy -of hierarchy based explicitly on an ideology of a parallel development of institutions concerned with the control of female sexuality... [Whenever] purity is the primary idiom of status differentiation, there is certain to be a major preoccupation with the maintenance of female chastity. This is especially so in India where the purity of the caste is a direct function of the purity of its womenfolk. The male members of the caste are in large measure dependent for their status rating on the purity of their women (Allen, 1982). It is commonly acceptable that culture dominates the personality of people. In many cultures, arranged or forced marriages are still very common, often resulting in sexual abuse. Women often do not have the same rights regarding divorce or inheritance. Polygamy is also a cause of discrimination (Spagnoli, 2008). As (Clafer, 1997) states, that standards Norms are that standards that define the obligatory and expected behaviors of people in various situations. This reflects belief of society about correct and incorrect behaviors. Once these behaviors become second nature, members of a society, do not able to analyze every situation consciously and decide what there appropriate actions ought to be. Norms also can inhibit the type of thinking that might result in challenges to the dominant members of society (Dr. Safdar Rehman Ghazi, 2011, p. 102).In Nepalese society; usually, girls and women take meals last in the family as the norms of specific ethnic groups. They have to serve the food first to the elderly people, male members and children of the family before taking food themselves. They have to make do with the remaining food after the males, elderly and children eat. On the other hand they prefer to provide nutritious food to their sons first by considering that the boys will have to do hard work in future to earn money for the family. They provide such food to daughters after providing for their sons. Because of this, the women are malnourished compared to the men and it is even more difficult to go outside to do hard work (SAMUHIK ABHIYAN, Mar 2008, p. 37). 
ISSN: 2362-1303 (Paper) | eISSN: 2362-1311(Online)

JOURNAL OF ADVANCED ACADEMIC RESEARCH (JAAR)

Similarly, religion is one culture of people. Religion creates one rule to control the society. People may not ignore the basic belief of religion so it may determine the level of gender disparity in society. The previous study explained that one of the main causes of gender discrimination is religion. Many religions place women below men, and create a patriarchal society. Religion was, to Marx, "the opium of the people" (Marx 7 Engels, 1964; Stark \& Bainbridge, 1996). Ellis (1986) referred to religion as a form of psychopathology. But in this study, less than $50 \%$ (only around $42 \%$ ) agreed that religion causes the gender disparity.

The study found that more than 50\% respondents agreed that level of political awareness causes the gender disparity in Nepal. The previous study showed that in terms of ethnic participation in the political parties and their sister organizations; there is overwhelming majority of the Brahmins and Chhetries. From the inclusion perspective, status of hill Janajati and Dalit is rather satisfactory but Terai Middle Caste and Terai Janajati representing a huge portion of population fall far behind (Nepal R. S., 2009, p. 9). Women's inclusion in decision making in local governance remains a challenge. Proportionally, their inclusion is far lower at the local level (around 10\%) than at the national level (33\%). This meets local governance reservations of one woman member in each of the VDCs/DDCs but it is clear that these are way below national reservations (DFIDN Nepal Operational Plan: Gender Equality and Social Inclusion Annex, 2011).

Gender based division of labour also found causes to gender disparity. According to the Gurung 1995; Brown 1997, in the context of rural Nepal, gender analysis is critical. Women are largely responsible for the day-today today tasks within the farming system. Cash crop production and the migration of males to urban work centers is increasing the workload of rural Nepali women (2003, p. 338).

\section{Conclusion}

Gender disparity is one great problem of Nepal. It causes the problem in social change and development. By nature, male and female are born equally and have equal rights in society and Nation. The study found that more than $88 \%$ agreed patriarchy system causes the gender disparity followed by around $51 \%$ agreed on culture taboos, $85 \%$ agreed on social perception toward gender, $41 \%$ agreed on religious belief, $92 \%$ agreed on illiteracy, $88 \%$ agreed on income, $52 \%$ agreed on lack of political awareness and $89 \%$ agreed on gender based division of labor. Nepal is announced as the secular (irreligious) country which gave the opportunity to accept the any religion of own interest. So, it may be cause that less than $50 \%$ people agreed the role of religion to create the gender disparity in society. Now, people become free from the rule of religion. They want to change their religion if they felt problem because of the rigid norms of religion. Basically, economic sources, social perception and patriarchy system were prevailed in the all types of society so the study found that there was need of further research to explore the corrective measure to address the socio-culture causes of gender disparity. 
ISSN: 2362-1303 (Paper) | eISSN: 2362-1311(Online)

JOURNAL OF ADVANCED ACADEMIC RESEARCH (JAAR)

January 2015

\section{References}

Allen, M. (1982). 'Introduction: The Hindu View of Women' . In M. a. Allen, 'Women in India and Nepal'. Canberra: Australian National University.

Baker, T. L. (1999). Doing Social Research (Third Edition). Singapore: McGraw Hill.

Brown, S. (2003). Spatial Analysis of Socioeconomic Issues: Gender and GIS in Nepal. Mountain Research and Development, 23(4), 338-344.

Clafer, H. (1997). Women and equality changing patterns in American culture;. USA: Oxford University Press.

Dr. Safdar Rehman Ghazi, D. S. ( 2011, March). Family Structural Norms Leading to Gender Disparity in Pakistan. Asian Social Science, Vol. 7, (No. 3), 101-107.

Heald, M. H. (2010). Sociology : Themes and Perspectives. New Delhi, India: OXFORD University Press.

Nepal, R. S. (2009). Women's Political Participation,Empowerment and Inclusions in Nepal: Survey Report and Strategic Action Plan, 2009. Kathmandu: Renaissance Society Nepal, Women's Democratic Network, Central Committee and United Nations Development fund for Women (UNIFEM).

Ngozi C Mbonu, B. V. (2010). Gender-related power differences, beliefs and reactions towards people living with HIV/AIDS: an urban study in Nigeria. BMC Public Health, 1-10.

Rao, C. N. (2008). Sociology: principles of sociology with an Introduction to Social Thought. Ram Nagar, New Delhi: S. Chand \& Company Ltd.

SAMUHIK ABHIYAN. (Mar 2008). GENDER \& SOCIAL DISCRIMINATION STUDY: A Comprehensive Assessment on Gender \& Caste Based Discrimination in the Hill Districts of Mid and Far Western Development Regions. Kathmandu Nepal: Government of Nepal/ Government of Finland Rural Village Water Resources Management Project $(R V W R M P)$.

Spagnoli, F. (2008, May 9). Retrieved August 20, 2012, from A.P.A. - Blog: http://filipspagnoli.wordpress.com/2008/05/09/human-rights-facts-10/ 